\title{
Universiteit
}

Leiden

The Netherlands

\section{The life and death of public organizations: $A$ question of institutional design?}

Boin, R.A.; Kuipers, S.L.; Steenbergen, M.

\section{Citation}

Boin, R. A., Kuipers, S. L., \& Steenbergen, M. (2010). The life and death of public organizations: A question of institutional design? Governance-An International Journal Of Policy Administration And Institutions, 23(3), 385-410. doi:10.1111/j.1468-0491.2010.01487.x

Version: $\quad$ Not Applicable (or Unknown)

License: $\quad$ Leiden University Non-exclusive license

Downloaded from: $\quad$ https://hdl.handle.net/1887/30130

Note: To cite this publication please use the final published version (if applicable). 


\title{
The Life and Death of Public Organizations: A Question of Institutional Design?
}

\author{
ARJEN BOIN*, SANNEKE KUIPERS**, and \\ MARCO STEENBERGEN***
}

\begin{abstract}
Why do some public organizations grow old and others die young? Since Herbert Kaufman first posed this question, considerable research has been devoted to answering it. The findings of that research suggest that the design of new public organizations affects, to a significant degree, their survival chances. In this article, we test whether and how "design factors" affected the durability of the so-called New Deal organizations initiated under FDR's first term. Our findings confirm that design factors do matter, but their effects change over time. We draw out some potential implications for institutional design and sketch a renewed research agenda to determine why some public organizations survive environmental pressure whereas others succumb to it.
\end{abstract}

It has long been an article of faith among political scientists and public administration scholars that government organizations live long and die hard (Downs 1967; Lowi 1979). In his classic Are Government Organizations Immortal? Herbert Kaufman (1976) set out to investigate the longevity of these organizations. His "pilot investigation" found that the great majority of U.S. federal organizations persist rather undisturbed. Kaufman (1976, 69) hypothesized that organizational survival is a function of organizational adaptability to environmental contingencies, but he was quick to point out the limits of his findings.

More recently, David Lewis followed up on Kaufman's pioneering research with a large-scale study of U.S. federal organizations in the period 1946-1997 (Lewis 2002, 2004; see also Carpenter and Lewis 2004). Lewis (2002) found that governmental organizations are far from immortal. In fact, many organizations in his population were terminated. Lewis also offers a different explanation for the longevity of public organizations: Their survival appears to be a function of institutional design (Lewis 2002). Public organizations that are "endowed" with certain structural features-such as political insulation, a specific organizational structure, and statutory recognition-enjoy higher survival chances than those without these birth characteristics.

\footnotetext{
*Louisiana State University and Utrecht University

**Leiden University

***University of Bern
}

Governance: An International Journal of Policy, Administration, and Institutions, Vol. 23, No. 3, July 2010 (pp. 385-410).

(c) 2010 Wiley Periodicals, Inc., 350 Main St., Malden, MA 02148, USA, and 9600 Garsington Road, Oxford, OX4 2DQ, UK. ISSN 0952-1895 
This is a remarkable finding. It suggests that by insulating a new public organization from presidential interference, politicians can "hardwire" an organization against future efforts to terminate it. If young organizations can be infused with "some kind of natural immunity" to environmental pressure, as Kaufman $(1976,1)$ mused and Lewis suggests, this could have serious consequences for the practice of designing new public organizations.

The idea that "design matters" finds support in rational choice theory, in particular principal-agent models (cf. McCubbins, Noll, and Weingast 1989; Moe 1989). It resonates with the classic yet slightly discounted premise in organization theory, which holds that an organization's structure determines to a significant degree its functioning and performance (e.g., Galbraith 1977; Lorsch and Lawrence 1970). It chimes with the often heard yet rarely investigated assertion that the early years of an organization significantly affect its further development. ${ }^{1}$ It sits well with path dependency theories, which explain why initial choices have long-term effects on the future of an organization or policy sector (Krasner 1984; Pierson 2000).

Design plays a far less prominent role, however, in theories of public organizations, which tend to emphasize the importance of resources, constituencies, interests, leaders, legitimacy, bureaucratic culture, and politics (Dilulio 1994; Kaufman 1981; Wilson 1989). If empirical studies of public organizations hold any advice for the designers of new organizations, it would be the appointment of a "strong leader" and a record of high performance, which provide a young public organization with a "shield" against political interference (Doig and Hargrove 1987; Lewis 1980; Riccucci 1995). In this line of thinking, organizational survival is a function of adaptive capacity (cf. Aldrich 1999; Kaufman 1976).

The findings of Lewis $(2002,2004)$ thus pose a serious challenge to the received wisdom in the field of public organization research. They also raise thorny questions. The idea of "hardwired" public organizations reinforces a traditional and rather widespread fear of "run-away" public bureaucracies that routinely defy political preferences and act on their own accord (e.g., Boin and Goodin 2007; Goodsell 2003; Gouldner 1959; Perrow 1986; Rose and Davies 1994; Wood and Waterman 1994). Lewis $(2004,401)$ echoes a deep-seated concern when he asserts that "presidents increasingly are faced with an accumulation of agencies over which they have little control."

This article scrutinizes the "design thesis" as forwarded by Lewis. We study the effects of institutional design in a special population: the New Deal organizations, which saw the light during President Franklin Roosevelt's first term (1933-1936).

From a methodological perspective, the New Deal organizations constitute an excellent test bed for the impact of design characteristics on survival because we are able to hold constant a wide range of other birth conditions. All of these organizations came about during an economic 
crisis, under a Democratic president, and under a Democrat-controlled Congress, at a time when social reforms mediated by public bureaucracies were quite novel. We thus are dealing with a relatively homogeneous set of cases, which reduces the sensitivity to unobserved bias (Rosenbaum 2005).

In this article, we build on the work of Lewis (2003) and explore whether design factors can explain the survival rate of the New Deal organizations. It appears that "birth characteristics" of New Deal organizations matter, but they matter in different ways and during different life phases. This finding suggests that the capacity to adapt is as important as clever design.

\section{Explaining Durability: The Design Thesis}

The thesis of "impressive durability" runs through much of the classic work in classic public administration (Carpenter and Lewis 2004, 203). ${ }^{2}$ Yet public organizations do die. Kaufman (1976) found that $15 \%$ of the U.S. federal agencies that existed in 1923 had disappeared in 1973. This may not seem a high number, but Kaufman's $(1976,27)$ selection of organizations was-as he readily admitted-biased "heavily in favor of continuity." His database largely consisted of public organizations that had been set up under the Constitution of 1789. In other words, these were organizations that at the time reflected the core functions of the state, which, we may assume, are subject to less alteration than the public organizations and policy aims that saw the light during the more expansive government of the twentieth century. ${ }^{3}$ Indeed, Lewis (2003) found that not even $40 \%$ of the 426 U.S. federal organizations that existed in 1946 still existed in $1997 .^{4}$

This leaves us with the question of why some public organizations die whereas others persist. The simplest and most plausible explanation for an organization's demise is perhaps a functional one. It holds that an organization that no longer serves its original purpose because that purpose has been rendered obsolete faces inevitable termination. The Selective Service System, for instance, was a powerful public agency until the Pentagon decided to shift toward an all-volunteer army. The Steamboat Inspection Service, the Bituminous Coal Commission, and the Fixed Nitrogen Research Lab clearly belong to a different era.

But there are (too) many examples that undermine a functional explanation. Some organizations last surprisingly long. The U.S. Bureau of Mining was established in the early twentieth century to increase the safety of mine workers. This bureau survived radical change in the industry as well as the creation (1973) of a rival agency-the Mining Enforcement and Safety Administration-with the same mission (regulate and inspect mine safety). In 1995, the incoming Republican majority suddenly denied the U.S. Bureau of Mining its appropriation and dismantled the organization within three months (more than 1,200 employees lost their 
jobs). In the same year, Congress eliminated the Federal Helium Reserve, an agency created in the 1920s to supply the nation's fleet of helium-filled airships (Light 1999, 502). The same Congress also targeted the United States Geological Services for termination, but this organization "persisted as it had since its creation in 1879" (Lewis 2002, 89).

An alternative and more solid explanation combines two types of explanations. The first type focuses on environmental dynamics that create political opportunities to initiate termination efforts. It points out that political preferences, priorities, and perceptions change over time, budgets decrease, and coalitions shift. Such dynamics may suddenly cast the routine performance of a public organization-its accomplishments and its failures-in a different light. It may provide a window of opportunity for political entrepreneurs to politicize the performance of a public organization (Kingdon 1984), which allows incoming majorities to terminate pet organizations of losing incumbents, especially if these organizations embody the political aspirations of the losers (cf. Carpenter and Lewis 2004). In this line of argument, political turnover exposes vulnerable organizations to the threat of termination.

The second explanation identifies the birth characteristics that render a public organization more or less vulnerable to such termination efforts (Kaufman 1976; Lewis 2003). Durability then becomes a function of design or birth characteristics. This explanation recognizes that political founders of new organizations may try to protect their "offspring" from future interference by political opponents-especially future presidents with a different agenda-through "hardwiring": insulating the young organization from the environmental dynamics described above. ${ }^{5}$

In his analysis of federal organizations, Lewis $(2002,2003)$ found that structural insulation from potential political interference is a powerful predictor of organizational survival. A new agency that is placed outside existing bureaucratic agencies, is headed by officials who serve fixed terms, and has party limitations on appointments runs a significantly lower risk of termination than counterparts without these design features (Lewis 2003, 154). Organizations without a statutory origin appear especially vulnerable: organizations established by executive order tend to be abolished more easily (cf. Kaufman 1976). It seems fair to conclude that a young public organization endowed with a formal degree of autonomy enjoys better survival chances. ${ }^{6}$

This "design" explanation runs counter to received wisdom in the field of public administration, which holds that organizations and policies rarely, if ever, follow blueprints or "design" requirements (Feldman 1988; Goodin 1996; Handler 1986; Hood 1976; Kaufman 1971; Van Gunsteren 1976). These authors suggest that institutional adaptation, flexibility, and resilience may be more important, allowing public organizations to escape their impending termination by reinventing themselves. ${ }^{7}$ Moreover, the "design explanation" revives serious questions about the desirability of institutional design. If it were possible to design public organizations into 
perpetuity, this could have grave consequences for the democratic nature of such institutions.

We decided to submit the design thesis—as forwarded by Lewis— to an additional, rigorous test. We selected a population of organizations that were set up in an era marked by societal crisis: the New Deal organizations. The New Deal arguably marked the beginning of massive government intervention through the creation of public organizations (Arnold 1986; Egger 1975). These organizations were initiated by a president and Congress that had little experience in institutional design. In fact, these organizations were established during a time when the merits of design and the legitimacy of extensive administrative policymaking were in serious question.

Hastily conceived and heavily targeted, this population would seem extremely vulnerable to extermination efforts down the road. If we find that the surviving organizations possessed the birth characteristics that are thought to enhance durability, we will have an extremely solid confirmation of the design thesis. Let us now see how the design thesis fared in this population.

\section{Revisiting the New Deal Organizations: Population Characteristics}

In this article, we explore whether the design factors identified by Lewis can explain the survival variance in the population of New Deal organizations set up between 1933 and 1936. ${ }^{8}$ During this period, 63 federal organizations were created (see the Appendix). Some have subsequently become lasting institutions (think of the Tennessee Valley Authority, the Social Security Administration, and the Securities and Exchange Commission), while others have quietly disappeared. In 2007, 16 of these organizations (25\%) still existed.

Most New Deal organizations either perished at a fairly young age or grew respectably old (few died middle-aged). Roughly half $(54 \%)$ of the New Deal organizations did not live longer than 12 years, which corresponds with the early death rate found by Lewis (49\%). ${ }^{9}$ These organizations were abolished during the 73rd to 79th Congress (see Figure 1), which means they never saw a Republican Congress or president. The New Deal thus "ate quite a few of its own children."10

Intriguingly, $83 \%$ of all perished New Deal organizations were abolished by a Democratic president and Congress, whereas Democrats abolished only $45 \%$ of the perished organizations in Lewis's population. Republican presidents and majorities can only claim 15\% of the New Deal casualties. The Reagan administration, with its promise to cutback on bureaucracy, did not abolish a single New Deal organization.

The 16 surviving New Deal organizations weathered various wars, 12 presidents, three decades of Republican rein, major recessions, the advent of the computer age, the backlash against "big government," and the rise of New Public Management. Were these lasting institutions "hardwired" 


\section{FIGURE 1}

\section{Terminations per Congress}

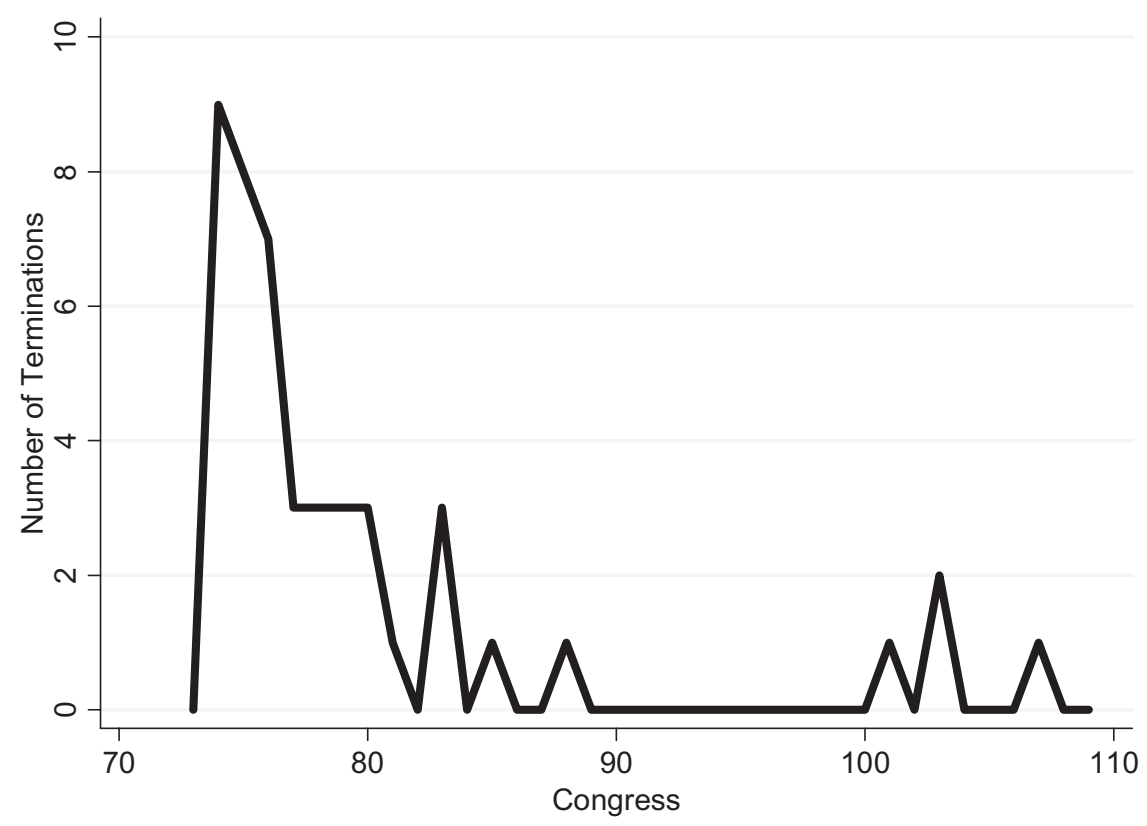

for survival during their birth? Did the nonsurvivors lack institutional safeguards against presidential intervention? To answer these questions, we checked whether and how (combinations of) birth characteristics relate to the durability of New Deal organizations.

We collected data on all U.S. federal government organizations established during the first years of the New Deal. Following Lewis, we selected the organizations that were newly listed in the United States Government Manual (USGM) of 1935, 1936, and 1937. ${ }^{11}$ This data set includes cabinet departments, administrations, bureaus, commissions, boards, government corporations, and large offices. It excludes bureaus and offices that were too small to be included in the USGM.

We should note how difficult it can be to determine what constitutes a new organization and when one is abolished (Emmerich 1971; Whitnah 1983). Organizations that were the result of a merger or that were split off from existing organizations (e.g., a division of a bureau that becomes a separate bureau) are here considered new. In case of doubt, we considered whether the new entry in the USGM had (1) a new name, (2) an organization chart that differed from its predecessor, and (3) new leadership. ${ }^{12}$

We use the same criteria to determine whether an organization has been terminated. A merger of organizations or a split into two or more 
organizations counts as a termination. When organizations are only changed in name and some of their functions, they are not considered to be abolished. ${ }^{13}$

Our population of 63 is considerably smaller than the one studied by Lewis. Appropriate caution should be taken in generalizing the results to a larger population of public organizations. But while relatively small, the size of this population does allow us to draw statistically sound conclusions. The use of a survival analysis (or event duration analysis) creates an $N$ that equals each agency times the number of years it existed $(n=1,854)$. This number of observations makes for robust conclusions.

Following Lewis (2003), we coded the New Deal organizations on the dependent variable (age/survival) and a set of design attributes (location, hierarchical independence, sunset, legislative underpinning, governing structure). We studied the absence or presence of these organizational attributes in the first two years of the organization's existence and related them to the age of the organization (see Table 1 for the organizational attributes of this sample). In addition, we coded for several controls pertaining to organization type and the political and economic conditions throughout an organization's life. Let us now describe these variables in more detail.

\section{Dependent Variable}

The dependent variable is organizational life span, which is measured as the duration in years between the creation and termination of an organization. The termination year is the year when the organization was formally abolished, absorbed in a merger, or split into two or more entities. Sixteen organizations (about $25 \%$ ) were not terminated by the end of 2007, the end of our observation period, and will hence be treated as right-censored cases (Kleinbaum and Klein 2005).

We use the survivor function to obtain a first impression of the likelihood of survival past a certain time point. Figure 2 shows the KaplanMeier estimate of this function, including the $95 \%$ confidence interval. The survival function drops off steeply for durations up to 20 years and then evens out. The probability of surviving past 10 years is slightly over 0.5 (by point estimate), suggesting a relatively short life span for most organizations that were created during Roosevelt's first term. On the other hand, the location of the asymptote of the survivor function suggests that longterm survival chances are significantly better than nil, a finding that is explained by the 16 organizations that continue to survive. Another way to look at survival prospects is that $19(30.2 \%)$ of the organizations existed for 5 years or less, while $20(31.7 \%)$ survived for at least 50 years.

\section{Independent Variables}

The first independent variable is location, which refers to the organization's proximity to the president. It is measured on a scale that runs from 
TABLE 1

Organizational Attributes of the Sample

Average

LifeSpan

Attribute

N

$\%$

(years)

Independence (created without any layers of

bureaucratic organization above it):

Agency inside bureaucracy

$36 \quad 57.1$

22.8

Agency outside bureaucracy

27

42.9

35.9

Commission/board structure:

Absent

33

52.4

23.6

Present

30

47.6

33.7

Location within a cabinet department:

No

42

66.7

32.3

Yes

21

33.3

20.6

Creation by executive or departmental order:

No

Yes

55

87.3

31.3

Creation by law:

No

Yes

8

12.7

60.3

22.8

Sunset clause:

Absent

39.7

36.9

Present

52

82.5

29.8

11

17.5

21.6

Relief organization:

No

55

87.3

31.3

Yes

8

12.7

Type of organization:

Foreign affairs

Social policy

3.2

43.0

Monetary policy

General

$\begin{array}{rrr}2 & 3.2 & 43.0 \\ 21 & 33.3 & 21.3 \\ 24 & 38.1 & 33.6 \\ 16 & 25.4 & 28.0\end{array}$

Note: $\mathrm{N}=63$.

1 to 5. Lewis (2003) hypothesized that a location near to the president would make it easier to abolish an organization. Agencies located in the executive office score 1, while government corporations or agencies located in the judicial or legislative branch score 5. Agencies located in the cabinet score 2, independent administrations are coded 3, and independent commissions are coded 4. Following Lewis (2003), we expect a negative effect from close proximity to the president; increased distance should make an organization less vulnerable to termination.

The second attribute that we consider is hierarchical independence. Lewis (2003) suspected that an organization's formal position-being placed in or outside existing organizational structures-could affect its survival prospects. A case scores 0 if it is a (sub)division of an existing public organization or operates in another form under the direct formal authority of a public organization. If the new organization operates outside the 


\section{FIGURE 2}

\section{Survivor Function}

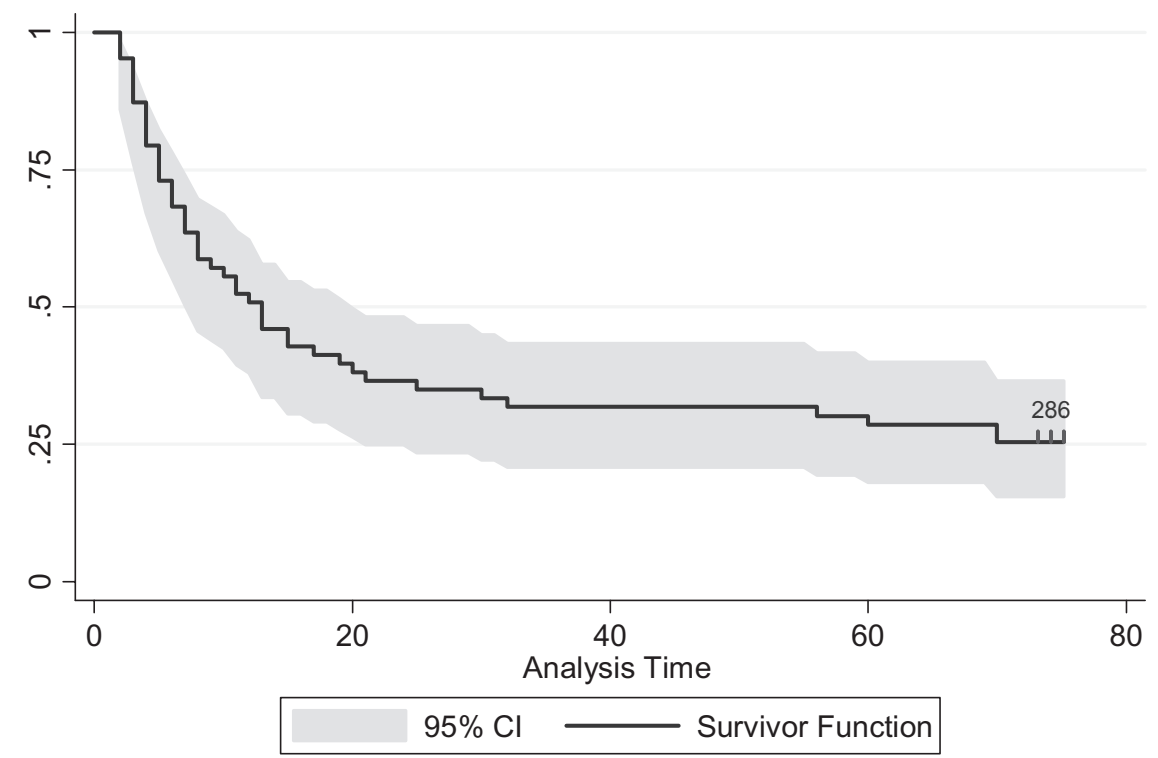

Note: Graph displays the Kaplan-Meier estimate of the survivor function (thick line) and its 95\% confidence interval (gray band). Censored observations are indicated by hash marks; the number of censored cases is indicated above the hash marks.

direct influence sphere of any other bureau, administration, commission, or corporation, it scores 1 . We expect that organizational independence will increase the life span of a new organization.

Third, we consider whether an organization has a board or commission structure. This predictor indicates whether the new organization is headed by a board, a commission, or a single administrator (who tends to be politically appointed). A case scores 1 if the organization is headed by a commission or a board. Sometimes the USGM explicitly mentions this; often the commission/board members are listed as such. A case scores 0 if it has no listing of a commission, no board, or when the USGM explicitly mentions a single administrator. Lewis (2003) expected agencies with a commission or board structure to be relatively immune to political appointments and thus to political turnover and presidential interference. It follows, then, that a positive relationship can be expected between the presence of a board/commission structure and an organization's longevity.

Our fourth predictor is insulation from the executive. Insulation is a recode of the location variable discussed above. Specifically, we used two dichotomous variables for indicating the distance to the president (or what Lewis calls "political insulation"). ${ }^{14}$ We simply coded whether or not an 
agency is part of the executive office/cabinet structure. Sticking with Lewis's (2003) findings, we expect a negative relationship between an organization's proximity to the executive office and its survival prospects.

Fifth, we consider the legislative origin of the New Deal organizations. Lewis (2003) discerns four different categories of statutory underpinning: (1) by legislation, (2) by reorganization plan, (3) by executive order, or (4) by departmental order. As the information on this variable (as captured in the USGM) was limited, we collapsed Lewis's categories into two categories of statutory origin (weak or strong). The "strong" category includes those organizations established by law, while the "weak" category includes those organizations created by departmental or executive order, without a legislative mandate. The middle categories serve as the baseline. We determine for each case whether or not it was created by law, which means that Congress voted in favor of legislation drafted to establish the organization at hand. We expect statutory recognition by law to enhance survival. Correspondingly, organizations that were initiated by departmental or executive order should display greater mortality rates.

The sixth predictor is the presence of a sunset clause. Some organizations die young because they were never intended to grow old (e.g., project organizations). These organizations are designed to be terminated after fulfilling their mission. We therefore check for each organization in our population whether a so-called sunset clause formally limited its life span. A case scores 0 on this predictor if nothing is stipulated in the USGM at the time of its creation. The organization scores 1 if it was created with a sunset clause, markers of which are a fixed budget or the stipulation of an official cutoff date. It follows from the intentional temporality indicated by a sunset clause that we expect a negative relationship between the presence of such a clause and an organization's life span.

Following Lewis (2003), we control for unemployment rate, major wars $(0,1),{ }^{15}$ presidential second terms $(0,1)$, new administrations $(0,1)$, the presence of an unfriendly (i.e., Republican dominated) House $(0,1)$, and the presence of an unfriendly (i.e., Republican) president $(0,1) .{ }^{16}$ The coding of these variables is similar to Lewis (2003).

We added two control variables, which appear especially relevant for this particular population. The first of these marks whether the organization was a relief organization or not. During the New Deal, several relief organizations were created to deal with the deep poverty and steep unemployment rates that defined the era. Mission completion could take away an organization's reason for existence, which, it stands to reason, would cut its life short (even in the absence of a formal sunset clause). A second control variable is based on Lowi's (1979) distinction between different policy sectors and characterizes organizations as being constitutive, distributive, redistributive, or regulatory. We include this predictor to capture the potential that organizational hazard rates vary by policy domain. For analytical purposes, we have created three dummy variables, treating constitutive policy agencies as the baseline category. 


\section{Findings and Discussion}

We analyze organizational survival analogously to Lewis (2003) by using an event duration model. A Cox regression model is a common choice for analyzing duration data that are censored and non-normally distributed. ${ }^{17}$ We implement this model using Efron's method for handling ties, which allows for different organizations to be terminated at the same point in time. The Cox model assumes that the effect of predictors remains constant over survival time (the proportional hazard assumption). This assumption is violated in several cases; where this happens, we have opted for the standard solution of interacting the predictor with the log of survival time.

\section{Agency Location and Survival}

We begin by considering the effect of agency location, that is, an agency's distance from the president. We use different models, one containing covariates similar to Lewis (2003) and two others considering two additional agency attributes: (1) whether an organization is a relief organization or not and (2) agency type. By using different model specifications we can assess the robustness of the results.

Table 2 shows the estimates of three different model specifications. Model 1 corresponds most closely to Lewis's (2003) specification. The location effect estimated here is both significant and in the expected negative direction. Thus, as agencies are further removed from the president they are less at risk of dissolution. Specifically, for a unit increase in distance, the hazard decreases by roughly $20 \%$. This finding is consistent with Lewis (2003). ${ }^{18}$

The result for location is not very robust, however. As soon as we include the additional controls, the effect of location becomes statistically insignificant (Model 2). Upon further examination, it turns out that this insignificance is due to the time-varying effect of location that emerges once the additional controls are included. Model 3 takes this into consideration and leads to a fundamentally different appraisal of location effects on agency survival. Initially, close proximity to the president actually enhances the prospect of agency survival. Only in the longer run does it become a liability and is a more distal location beneficial. The tipping point lies around 4.4 years (see Figure 3 ).

The changing character of the location effect with changing model specifications is, of course, only of interest if one accepts the need for additional controls. From a statistical perspective, it clearly is necessary to include agency type and note whether the New Deal organization was a relief organization. A Wald test setting the effects of the additional controls to zero yields a test statistic of $29.29, P<0.01$, revealing the statistical importance of those predictors. ${ }^{19}$

From a substantive perspective, it is also clear that the controls add a great deal to our understanding of agency survival. For instance, we learn 
TABLE 2

Agency Location and Survival

\begin{tabular}{|c|c|c|c|}
\hline Predictor & Model 1 & Model 2 & Model 3 \\
\hline Location & $\begin{array}{c}-0.230^{* *} \\
(0.116)\end{array}$ & $\begin{array}{c}-0.162 \\
(0.161)\end{array}$ & $\begin{array}{c}0.430 \\
(0.325)\end{array}$ \\
\hline Location $\times \ln (t)$ & & & $\begin{array}{c}-0.291^{*} \\
(0.148)\end{array}$ \\
\hline War & $\begin{array}{c}-0.379 \\
(0.623)\end{array}$ & $\begin{array}{c}0.201 \\
(0.657)\end{array}$ & $\begin{array}{c}0.290 \\
(0.629)\end{array}$ \\
\hline New president & $\begin{array}{c}0.786 \\
(0.540)\end{array}$ & $\begin{array}{c}0.591 \\
(0.588)\end{array}$ & $\begin{array}{c}0.767 \\
(0.652)\end{array}$ \\
\hline Second term & $\begin{array}{c}-0.469 \\
(0.630)\end{array}$ & $\begin{array}{c}-0.331 \\
(0.586)\end{array}$ & $\begin{array}{c}-0.478 \\
(0.586)\end{array}$ \\
\hline Unfriendly president & $\begin{array}{c}-0.028 \\
(0.994)\end{array}$ & $\begin{array}{c}-0.451 \\
(1.229)\end{array}$ & $\begin{array}{r}-0.730 \\
(1.035)\end{array}$ \\
\hline Unfriendly House & $\begin{array}{c}1.394 \\
(0.991)\end{array}$ & $\begin{array}{c}2.156+ \\
(1.115)\end{array}$ & $\begin{array}{c}2.069+ \\
(1.151)\end{array}$ \\
\hline Unemployment & $\begin{array}{c}-0.019 \\
(0.095)\end{array}$ & $\begin{array}{c}0.021 \\
(0.093)\end{array}$ & $\begin{array}{c}0.036 \\
(0.095)\end{array}$ \\
\hline Relief organization & & $\begin{array}{c}-10.190^{* *} \\
(3.585)\end{array}$ & $\begin{array}{c}-10.240^{* *} \\
(3.585)\end{array}$ \\
\hline Relief organization $\times \ln (t)$ & & $\begin{array}{l}6.410^{* *} \\
(1.792)\end{array}$ & $\begin{array}{c}6.436^{* *} \\
(1.797)\end{array}$ \\
\hline Distributive organization & & $\begin{array}{c}-2.372+ \\
(1.241)\end{array}$ & $\begin{array}{c}-3.181^{* *} \\
(1.161)\end{array}$ \\
\hline Distributive org. $\times \ln (t)$ & & $\begin{array}{c}0.829+ \\
(0.435)\end{array}$ & $\begin{array}{l}1.210^{* *} \\
(0.394)\end{array}$ \\
\hline Redistributive organization & & $\begin{array}{r}-1.300^{*} \\
(0.612)\end{array}$ & $\begin{array}{r}-1.294^{*} \\
(0.592)\end{array}$ \\
\hline Regulatory organization & & $\begin{array}{c}-0.265 \\
(0.459)\end{array}$ & $\begin{array}{c}-0.222 \\
(0.467)\end{array}$ \\
\hline Pseudo log-likelihood & -165.646 & -149.809 & -148.061 \\
\hline
\end{tabular}

Notes: Table entries are maximum likelihood estimates of the Cox proportional hazards model using the Efron method for handling ties. Cluster-corrected estimates appear in parentheses, where clustering is on organization id. $N=1,854$. ${ }^{* *} P<0.01,{ }^{*} P<0.05,+P<0.10$ (two-tailed).

that agency survival is negatively affected when an agency faces an unfriendly House of Representatives and positively (compared with constitutive agencies) when it is involved with redistributive policies. We also see that relief organizations initially tend to face less risk but that this reverses over time (the tipping point is just below five years). This result likely reflects the fact that these agencies were constituted to address the severe poverty and unemployment that characterized the early 1930s. After these problems subsided, their raison d'être disappeared (sunset clauses had little if anything to do with this). Finally, we observe that distributive organizations faced less risk initially and greater risk later on (with a tipping point around 13.8 years).

In sum, our results reveal a more complex pattern than Lewis (2003) found. Without additional controls, we replicate his result (greater 


\section{FIGURE 3}

\section{The Impact of Agency Location on Risk}

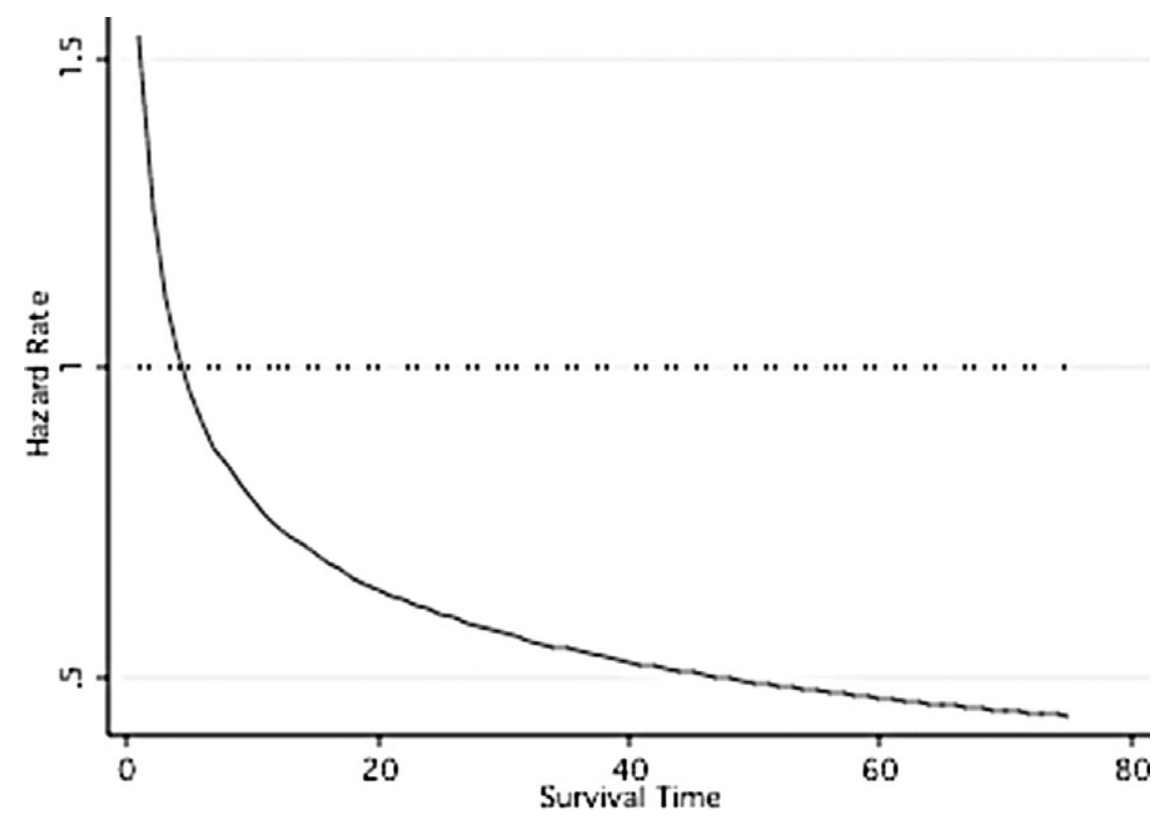

Notes: Graph shows predicted hazard rates for a unit increase in agency location as a function of survival time. The dashed reference line marks whether the hazard rate is greater or less than 1 .

distance to the president protects agencies from dissolution). With additional controls, however, distance appears to have two effects: Initially it puts agencies at risk and only in the longer run does it protect them against termination. To complicate matters even further, our recode of this variable provides different results yet again (see below).

\section{Agency Structure and Survival}

Let us now take a more detailed look at the other variables. Again, our strategy is to estimate models with Lewis's (2003) controls (Model 1) as well as a more extensive set of control variables (Model 2). The results are displayed in Table 3.

Model 1 suggests, in accordance with Lewis's findings, that several design characteristics contribute significantly to survival. Yet the characteristics that attain statistical significance turn out to have time-varying effects: Somewhere in history, the impact of the characteristics reverses signs. ${ }^{20}$ Allowing for time variation appears to be statistically prudent: Wald $\chi^{2}=10.14, P<0.05$, testing the null hypothesis that our independent variables do not interact with survival time. 


\section{TABLE 3}

Agency Structure and Survival

\begin{tabular}{|c|c|c|}
\hline Predictor & Model 1 & Model 2 \\
\hline \multirow[t]{2}{*}{ Sunset clause } & 0.581 & 0.509 \\
\hline & $(0.413)$ & $(0.451)$ \\
\hline \multirow[t]{2}{*}{ Commission/board structure } & $3.598^{*}$ & $3.447^{*}$ \\
\hline & $(1.499)$ & $(1.607)$ \\
\hline \multirow[t]{2}{*}{ Structure $\times \ln (t)$} & $-1.881^{*}$ & $-1.851^{*}$ \\
\hline & $(0.794)$ & $(0.874)$ \\
\hline \multirow[t]{2}{*}{ Independence } & $1.407+$ & $1.987^{*}$ \\
\hline & $(0.795)$ & $(0.987)$ \\
\hline \multirow[t]{2}{*}{ Independence $\times \ln (t)$} & $-0.892^{*}$ & $-1.171^{* *}$ \\
\hline & $(0.367)$ & $(0.442)$ \\
\hline \multirow[t]{2}{*}{ Located inside the executive } & -0.134 & 0.043 \\
\hline & $(0.378)$ & $(0.396)$ \\
\hline \multirow[t]{2}{*}{ Created by executive order } & 0.470 & 0.695 \\
\hline & $(0.410)$ & $(0.448)$ \\
\hline \multirow[t]{2}{*}{ Created by law } & 0.038 & 0.358 \\
\hline & $(0.397)$ & $(0.540)$ \\
\hline \multirow[t]{2}{*}{ War } & 0.195 & 0.417 \\
\hline & $(0.786)$ & $(0.750)$ \\
\hline \multirow[t]{2}{*}{ New president } & $1.008+$ & 0.956 \\
\hline & $(0.536)$ & $(0.582)$ \\
\hline \multirow[t]{2}{*}{ Second term } & -0.972 & -0.834 \\
\hline & $(0.717)$ & $(0.638)$ \\
\hline \multirow[t]{2}{*}{ Unfriendly president } & -1.405 & -1.475 \\
\hline & $(1.346)$ & $(1.367)$ \\
\hline \multirow[t]{2}{*}{ Unfriendly House } & 1.808 & $2.215^{*}$ \\
\hline & $(1.153)$ & $(1.093)$ \\
\hline \multirow[t]{2}{*}{ Unemployment } & 0.014 & 0.015 \\
\hline & $(0.098)$ & $(0.091)$ \\
\hline \multirow[t]{2}{*}{ Relief organization } & & -6.213 \\
\hline & & $(4.084)$ \\
\hline \multirow[t]{2}{*}{ Relief organization $\times \ln (t)$} & & $4.841^{*}$ \\
\hline & & $(2.059)$ \\
\hline \multirow[t]{2}{*}{ Distributive organization } & & 0.166 \\
\hline & & $(0.455)$ \\
\hline \multirow[t]{2}{*}{ Redistributive organization } & & $-5.378^{* *}$ \\
\hline & & $(1.962)$ \\
\hline \multirow[t]{2}{*}{ Redistributive org. $\times \ln (t)$} & & $1.773^{*}$ \\
\hline & & $(0.733)$ \\
\hline \multirow[t]{2}{*}{ Regulatory organization } & & 0.561 \\
\hline & & $(0.475)$ \\
\hline Pseudo log-likelihood & -148.485 & -134.846 \\
\hline
\end{tabular}

Notes: Table entries are maximum likelihood estimates of the Cox proportional hazards model using the Efron method for handling ties. Cluster-corrected estimates appear in parentheses, where clustering is on organization ID. $N=1,854$. ${ }^{* *} P<0.01,{ }^{*} P<0.05,+P<0.10$ (two-tailed). 


\section{FIGURE 4}

The Impact of Committee/Board Structure on the Hazard Rate

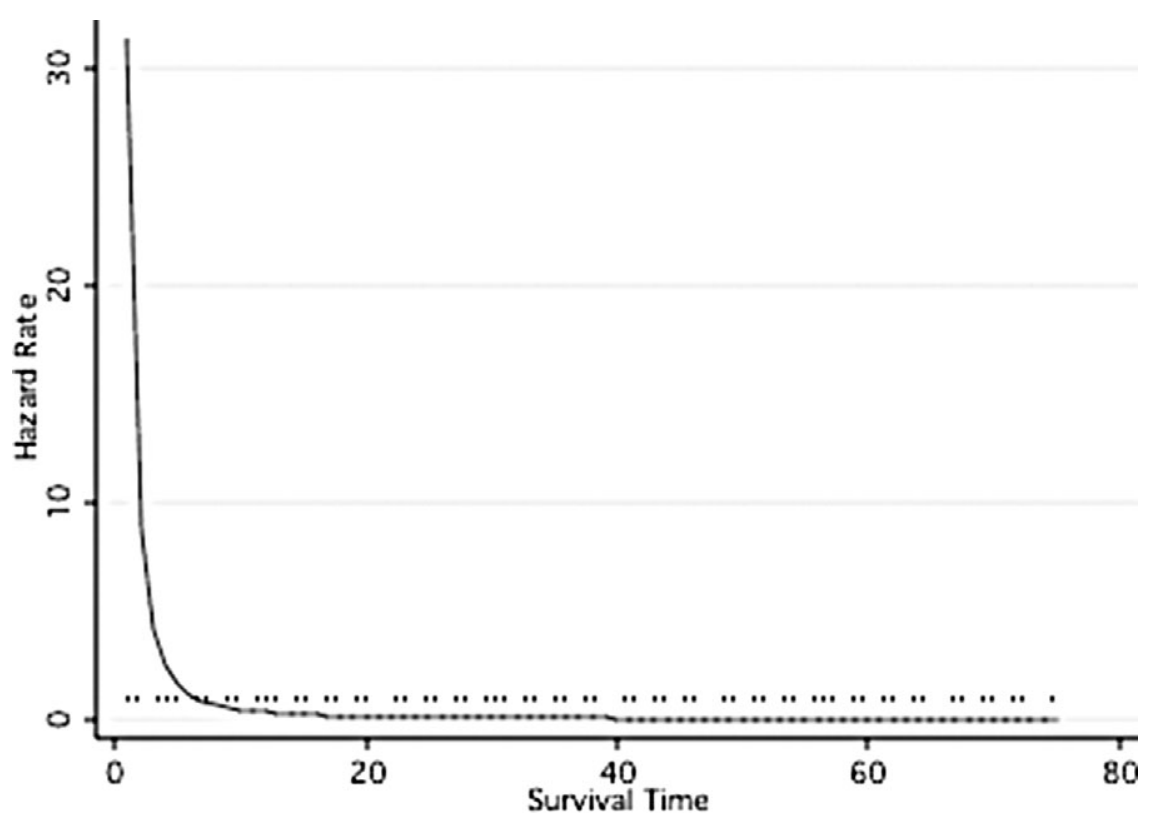

Notes: Graph shows the predicted hazard rate for agencies with a committee/board structure as a function of survival time. The dashed reference line marks the hazard for agencies with a different kind of organizational structure.

This pattern does not change with the additional controls in Model 2. As before, these controls are substantively important, as well as statistically necessary: Wald $\chi^{2}=31.95, P<0.01$. Again, the impact of agency location, having a committee or board structure, and being independent changes over time (Wald $\chi^{2}=9.08, P<0.05$ ).

Contrary to our expectation, having a committee/board structure increases an agency's risk initially. Only after around 6.5 years does this design feature seem to work to the advantage of an agency's survival (see Figure 4). Independence shows a similar pattern. Initially a liability, it becomes an asset for survival after about 5.5 years (see Figure 5).

Insulation, on the other hand, shows the reversed pattern. It protects agencies from dissolution in the short run but puts them in harm's way in the longer run, the tipping point being around 14 years (i.e., after FDR's presidency; see Figure 6). This finding is closer to Lewis's findings than the location variable, but it still shows time-dependence effects. From a statistical perspective, it appears that this recode provides a better way of measuring the influence of the executive than the location variable discussed above. 


\section{FIGURE 5}

\section{The Impact of Independence on the Hazard Rate}

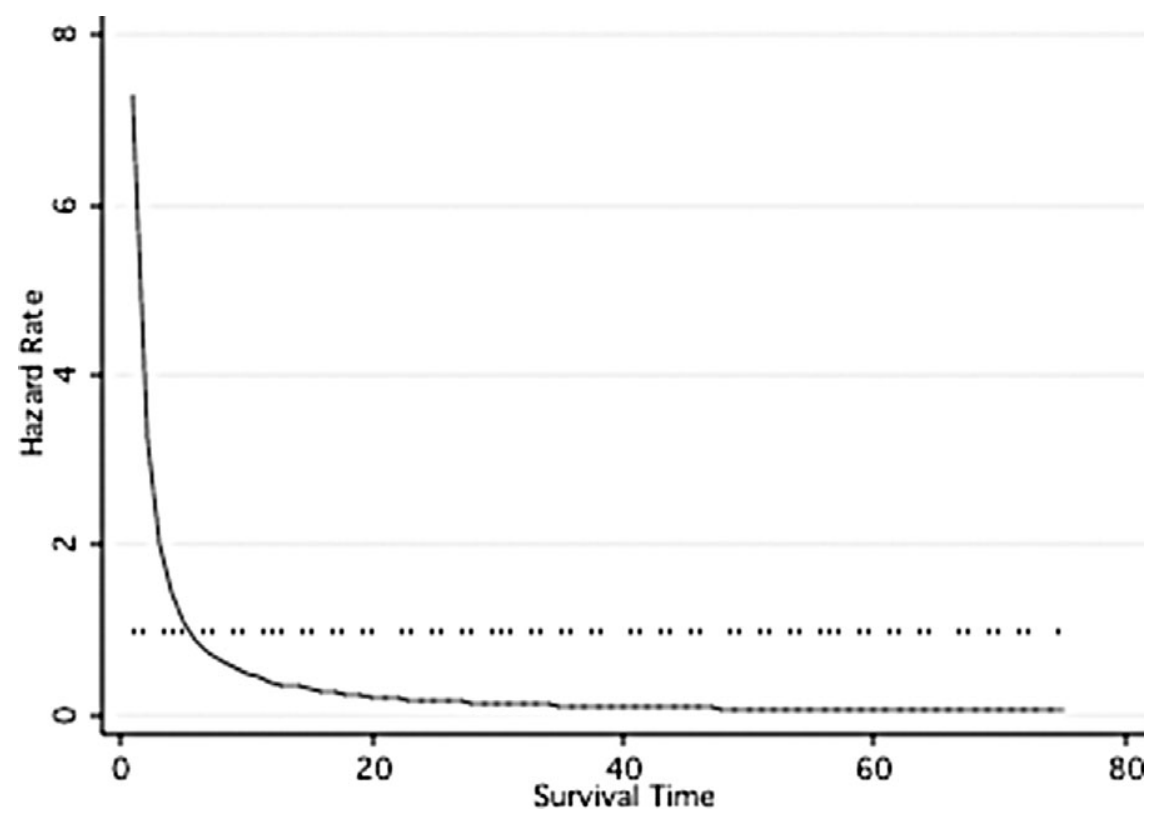

Notes: Graph shows the predicted hazard rate for independent agencies as a function of survival time. The dashed reference line marks the hazard for nonindependent agencies.

These results are considerably more complex than those reported by Lewis (2003). While he finds unidirectional effects of agency structure, we find that for our set of agencies, the effects change directions as a function of time at risk. Aside from location, insulation, committee/board structure, and independence, we observe no significant effects from agency attributes that were in place at the time of inception. ${ }^{21}$ The lack of a significant sunset clause effect is particularly intriguing: There is no apparent statistical association between providing an explicit agency termination date and the agency's longevity.

In summary, we can formulate two conclusions about the impact of institutional design on the survival of New Deal agencies. First, while three design variables attain statistical significance at conventional levels and another one emerges with a more generous choice of significance level, several of the design variables do not. Second, the effect of design choices does not appear to be constant. What looks like an excellent design choice in the short run in terms of agency location may become ineffective or perhaps even a liability in the longer run. Conversely, what looks like a bad design choice (e.g., commission/board structure) in the short run may prove to be an excellent design choice in the long run. 


\section{FIGURE 6}

\section{The Impact of Insulation on the Hazard Rate}

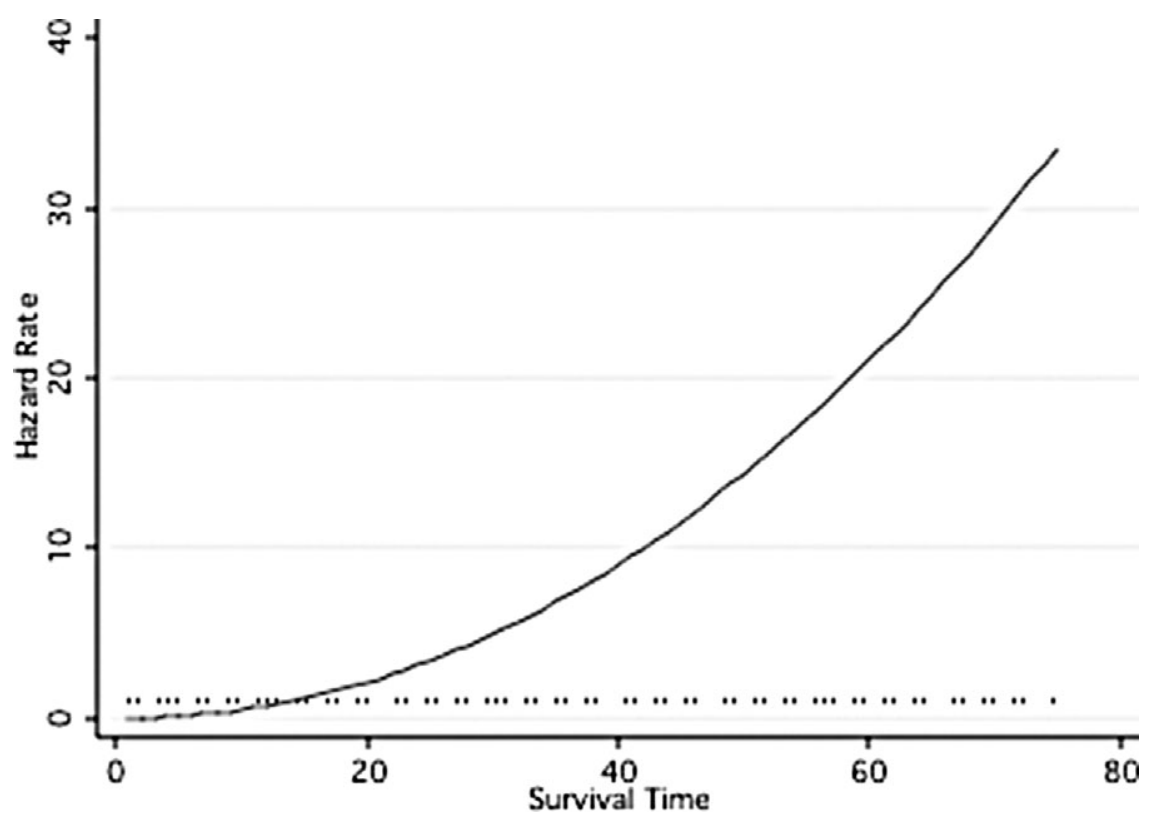

Notes: Graph shows the predicted hazard rate for insulated agencies as a function of survival time. The dashed reference line marks the hazardfor noninsulated/exposed agencies.

\section{Discussing Design Effects}

Our results sketch a somewhat different picture of the relation between agency design and survival than Lewis's (2003) results did. The effects of the variables change as the organizations age. Static generalizations about organizational lifetimes are not possible for our population.

The unique character of the New Deal population may explain at least part of the difference. The New Deal agencies were the brain children of a single administration and came into the world under unique economic, social, and political conditions. This combination of era and circumstances may well have played a role.

Our findings, however, may also implicate that the relation between agency design and survival sometimes is less straightforward than Lewis's (2003) findings suggest. Other factors may be at play.

Consider, for instance, the effects of sunset clauses. Even if there is a hint in our data that sunset clauses diminish the survival prospects of a new federal organization, the real question is why some New Deal organizations managed to survive such a clause. We must conclude that it is at least possible for public organizations to survive beyond firmly set execution dates. 
It is not hard to think of other factors that may be at play here. Perhaps some organizations somehow convince their patrons that life extension is beneficial to them and therefore necessary. Alternatively, we may speculate that the very existence of a sunset clause provides temporary if unintended refuge from critics: As the demise of the organization is seemingly guaranteed, why would opponents waste their time criticizing and attacking it? ${ }^{22}$ A sunset clause may serve as a powerful incentive for employees to perform well and prove that the organization is indispensable or to reinvent it before the bell tolls. A complementary hypothesis would speculate that sunset clauses serve a symbolic function during the conception phase, when critics need to be assured that the new organization will be terminated in time.

The idea that some organizations manage to overcome their "birth defects" fits the work of organization theorists who have documented how some public organizations reinvent their original missions and tailor their appearance to placate and please external stakeholders (Meyer and Rowan 1977; Perrow 1986; Selznick 1949; Wilson 1989). It fits Kaufman's (1976) hunch that "organizational adaptation" is a key variable. Furthermore, it supports Lewis's (2004) hypothesis that congruence between an organization's performance and Congressional preferences (gauged in terms of the legislative median's ideal point) is a crucial factor determining an organization's survival chances.

This line of reasoning sits well with the received wisdom that a public organization must earn its legitimacy (Suchman 1995; Wilson 1989). It is certainly helpful if organizational leaders can build their organization under protective guard, providing the organization with a honeymoon period during which it can find an effective and legitimate way of operating (cf. Boin and Christensen 2008). But insulation cannot save a young organization from widely perceived underperformance.

\section{Conclusion: Explaining Organizational Durability (Revisited)}

The purpose of this article has been to assess the impact of institutional design characteristics on the durability of New Deal organizations. We found that design features (or "birth characteristics") do matter, but they matter in different ways during the different life phases of public organizations. In its early years, they may protect an organization against the potential effects of environmental dynamics. But these beneficial effects may well work against an organization as it matures and becomes institutionalized.

All this suggests that our capacity to design public organizations for the long run is limited. This seems a plausible suggestion. Agency designers need to take heed of the risks that an agency runs here and now. However, they also need to anticipate future risks, which may be of a fundamentally different nature. What protects an agency in the short run may expose it in the long run and vice versa. Even if agency designers recognize the 
time-varying effects of design features, they may have a great deal of uncertainty about the exact location of the tipping point.

This may dispel some of the fear and suspicion that surround efforts of institutional design (cf. Boin and Goodin 2007). Some of the worst fears evoked by strong public institutions-such as shirking, uninhibited rent seeking, and blind pursuit of formal goals-would be well founded if a legislature or executive could not provide an agency with a credible threat of termination. The capacity to "hardwire" a public organization against future interference would essentially deprive future legislatures and executives of such a threat. It might take away an organization's incentives to adapt to a changing policy environment, which, in turn, would undermine its capacity to perform in an effective and responsive manner. It could, in other words, create a population of recalcitrant organizations that may be less interested to serve the needs of citizens.

To be sure, our analysis of New Deal agencies does not refute the design thesis as forwarded by Lewis. It does leave us with new questions. Our analysis shows that institutional design factors cannot fully explain the observed variance in durability of New Deal organizations. Well-protected New Deal organizations suffered early deaths, whereas seemingly exposed organizations have grown into public institutions that mark the American federal landscape today. Organization theory suggests alternative and plausible explanations, but these will have to be subjected to systematic analysis.

We propose a three-step strategy. The first step would take us back to the drawing board. It would be helpful to make a clear distinction between the politics of organizational creation (Grafton 1975), the early years of institutional development (Boin and Christensen 2008), the politics of agency adaptation and persistence (Doig 2001; Hargrove 1994; Wood and Waterman 1994), and the politics of agency termination (cf. Bardach 1976; Behn 1978). In addition, more work should be done to clearly define the crucial concepts of organizational birth and death.

The second step would consist of empirical exploration of selected New Deal organizations. We would study those organizations that were established as permanent tools for government intervention but were abolished in an early stage (such as the Agricultural Adjustment Administration, the National Recovery Administration, and the National Resources Planning Board). Could it be that they failed to establish legitimate routines and practices that were valued by their environment and that enhanced their performance? In addition, we would probe into the institutional histories of such highly contested organizations as the Securities and Exchange Commission or the Rural Electrification Administration to see how they survived. How did they manage to strike root? Anecdotic evidence suggests that an understanding of organizational life cycles would benefit from studying the execution of leadership tasks (Mashaw 1983; Parrish 1970; Selznick 1957). 
The final step would be to test the resulting hypotheses in other populations (including the one studied by Lewis). Only then can we tell if our findings are just an artifact of the New Deal era or reflect dynamics that emerge in other populations as well.

The most important finding of this article tells us that there is no silver bullet-no magic combination of design options-that will guarantee organizational survival. It would seem that the name of the game is not design for survival but design for adaptation. The best that designers may be able to do is to endow the organization with sufficient flexibility to adapt. Future research should investigate whether it is the ability to scan the environment and change one's organizational structure and mission that make it possible to survive long after the original raison d'etre has ceased to exist.

\section{Acknowledgments}

We thank Katja Kleinberg, Eline Spek, Sarike Verbiest, and Olaf van Vliet for their highly valuable case work. Michael Bauer, Frank Baumgartner, Warren Eller, Martijn Groenleer, Gerhard Hammerschmid, Dominik Hangartner, Erwin Hargrove, Paul 't Hart, David Lowery, Michael Kaeding, Celesta Kofman, and Torsten Selck provided instructive comments on earlier versions of this article. Workshop participants at the 21st Egos Colloquium in Berlin (July 2005), the Maxwell School Public Administration discussion seminar (Syracuse University, October 2005), and Leiden University Department of Public Administration's Victor de Stuers seminar (November 2006) also provided useful feedback. Finally, we wish to thank anonymous reviewers for their penetrating but constructive criticism, which helped us to improve this article.

\section{Notes}

1. As Seidman $(1998,138)$ puts it, "the first organization decision is crucial. The course of institutional development may be set irrevocably by the initial choice of administrative agency and by how the program is designed." According to Stinchcombe's (1965) "liability of newness" thesis, short-term survival pretty much ensures immortality.

2. Many researchers have wondered why some organizations "live" longer than others (Aldrich 1999; Carpenter and Lewis 2004; Hager et al. 1996; Kaufman 1976; Lewis 2002; Stinchcombe 1965; Strange 1998). In this section, we briefly summarize the most common explanations for survival of public organizations.

3. Moreover, Kaufman did not take into account the organizations that were created after 1923 or abolished prior to 1973 (organizations that existed briefly somewhere between these years were not included), which further biased his findings toward continuity.

4. Whereas Kaufman may have been somewhat conservative in his selection, Lewis adopted criteria that may have biased his findings toward a higher mortality rate (Lewis, for instance, coded a combination of name and 
function change as an organizational death whereas Kaufman spoke of organizational death only when the "boundaries around a group" had disappeared).

5. The term "hardwiring" is not well defined. It may refer to making a credible commitment to not exercising influence over an agency after it is created (McCubbins, Noll, and Weingast 1989). Or it may refer to including in the agency's design features that increase its durability (insulating the agency from the influence of others). We use the latter definition, which we paraphrase from Lewis $(2002,103)$.

6. Insulation is closely related to the concept of political autonomy. The idea that autonomy positively influences survival finds support in other studies. Political autonomy is generally considered an important characteristic of thriving and surviving public organizations (Boin 2001; Carpenter 2001; Lewis 2002, 2003; Sapolsky 1972; Selznick 1949; Wilson 1989). Wolf (1993) tested and confirmed the hypothesized positive relationship between autonomy and bureaucratic effectiveness. If we accept that the effectiveness of an organization will positively affect its reputation, we may infer that autonomy increases the likelihood of survival.

7. Classic examples include the Tennessee Valley Authority and the New York Port Authority (Hargrove 1994 and Doig 2001, respectively). The emphasis on adaptation corresponds with key findings in the literature on the rise and fall of civilizations (Diamond 2005; Tainter 1988).

8. Historians and political scientists do not always agree on the exact time boundaries of the New Deal period. Some consider only the first 100 days of FDR's presidency, others the first eight years. We adopt the period that corresponds with FDR's first term.

9. Carpenter and Lewis (2004) show that the hazard rate for federal organizations established after 1946 is substantially higher than average during the first 10-12 years of their lives. This is in line with findings of studies on business organizations (Brüderl and Schüssler 1990; Fichman and Levinthal 1991; Henderson 1999).

10. The observation is Erwin Hargrove's (personal communication).

11. The inclusion of an organization in the USGM provides "an easy, unbiased decision rule and indicates their importance" (Lewis 2003, codebook). The USGM was first published in 1935.

12. Here we depart from Lewis (2003), who considered an organization "new" if it had a new name and different functions from any previously existing agencies. The criteria used by Lewis result in significantly more creations and terminations. Using his criteria, the life span of the National Archives and Records Administration (see next footnote) would have added an extra creation and terminations to our data set (the same goes for the Social Security Administration).

13. In our view, the creation of the National Archives and Records Service (NARS) in 1949 did not qualify as a new organization because we see a strong continuity of the National Archives as established in 1934 (McCoy 1978). Wayne Grover remained the leader of the NARS. The organization remained in the same building, with the same staff.

14. We suspected that the limited number of New Deal agencies could distort our findings. In order to capture the "in" or "out" position that this variable seeks to capture, we grouped Lewis's (2003) variables into two categories. His categories 1 and 2 are now scored as "subject to direct presidential power" (1) or not (0). The categories 4 and 5 are scored as "politically insulated" (1) or not (0). The middle category, which is rather amorphous in terms of the types of organizations it contains, serves as the baseline category. 
15. World War II, the Korean War, the Vietnam War, and the war in Iraq (the second Persian Gulf War) all qualify as major wars in that they spanned multiple years.

16. Lewis also includes unified government and an interaction between unified government, unfriendly House, and unfriendly president. We omit the triple interaction because for our cases, the combination of an unfriendly House and president always implies unified government. Inclusion of the two-way interaction between unfriendly House and president usually resulted in estimation problems, as these variables pushed the likelihood function to one, thus resulting in astronomical parameter estimates and infinitesimally small standard errors. Whether we include or exclude this interaction does not affect the estimates for the design variables very much.

17. Compared with parametric survival models, the Cox model does not require any assumptions about the baseline hazard, a helpful feature because we do not have strong theory to suggest a particular distributional assumption.

18. Like Lewis (2003), we here assume that location is continuous. Treating it as categorical and using the first category (located in the executive office) as the baseline, however, it becomes obvious that almost all of the location effect is due to the contrast with this category. Specifically, the contrasts with categories 3 and 4 are significant at the 0.10 level, while that with category 5 is significant at the 0.05 level. The associated coefficients are all in the expected negative direction. However, none of the remaining contrasts are significant. That is, there are no significant changes in the hazard between agencies in categories 2 versus 3, 2 versus 4, 2 versus 5, 3 versus 4,3 versus 5, or 4 versus 5. It thus seems that it would suffice to include a simple dichotomy: Agencies closest to the president versus all other types (see the variable insulation, which is our recode of this variable).

19. Even after omitting the time-varying effects of relief and distributive organization type the statistical importance of the additional controls is evident: Wald $\chi^{2}=19.39, P<0.01$.

20. Indeed, when this time variation is not taken into consideration only insulation reaches statistical significance as a main effect (results available upon request).

21. Being a relief organization is also statistically significant, but we consider this predictor to be more about the mission than about the design of an organization.

22. We thank Frank de Zwart for suggesting this alternative explanation.

\section{References}

Aldrich, Howard E. 1999. Organizations Evolving. London: Sage Publications.

Arnold, Peri E. 1986. Making the Managerial Presidency. Lawrence: University Press of Kansas.

Bardach, Eugene. 1976. "Policy Termination as a Political Process." Policy Sciences 7 (2): 123-131.

Behn, Robert D. 1978. "How to Terminate a Public Policy." Policy Analysis 4 (3): 393-414.

Boin, Arjen. 2001. Crafting Public Institutions. Boulder, CO: Lynne Rienner.

Boin, Arjen, and Tom Christensen. 2008. "The Development of Public Institutions: Reconsidering the Role of Leadership." Administration and Society 40 (3): 271297.

Boin, Arjen, and Robert E. Goodin. 2007. “Institutionalizing Upstarts: The Demons of Deinstitutionalization." Acta Politica 42: 40-57.

Brüderl, Josef, and Rudolf Schüssler. 1990. "Organizational Mortality: The Liabilities of Newness and Adolescence." Administrative Science Quarterly 35: 530-547. 
Carpenter, Daniel P. 2001. The Forging of Bureaucratic Autonomy. Princeton, NJ: Princeton University Press.

Carpenter, Daniel P., and David E. Lewis. 2004. "Political Learning from Rare Events." Political Analysis 12 (3): 201-232.

Diamond, Jared. 2005. Collapse: How Societies Choose to Fail or Survive. London: Allan Lane.

DiIulio, John J., Jr. 1994. "Principled Agents: The Cultural Bases of Behavior in a Federal Government Bureaucracy." Journal of Public Administration Research and Theory 4 (3): 277-318.

Doig, James W. 2001. Empire on the Hudson. New York: Columbia University Press.

Doig, James W, and Erwin C. Hargrove, eds. 1987. Leadership and Innovation. Baltimore, MD: The Johns Hopkins University Press.

Downs, Anthony. 1967. Inside Bureaucracy. Boston: Little, Brown and Co.

Egger, Rowland. 1975. "The Period of Crisis: 1933-1945." In American Public Administration, ed. Frederick C. Mosher. Tuscaloosa: University of Alabama Press.

Emmerich, Herbert. 1971. Federal Organization and Administrative Management. Tuscaloosa: University of Alabama Press.

Feldman, Martha. 1988. Order without Design. Stanford, CA: Stanford University Press.

Fichman, Mark, and Daniel A. Levinthal. 1991. "Honeymoon and the Liability of Adolescence: A New Perspective on Duration Dependence in Social and Organizational Relationships." Academy of Management Review 18 (2): 442-468.

Galbraith, Jay R. 1977. Organization Design. Reading, MA: Addison-Wesley.

Goodin, Robert E., ed. 1996. The Theory of Institutional Design. Cambridge, UK: Cambridge University Press.

Goodsell, Charles T. 2003. The Case for Bureaucracy: A Public Administration Polemic. $4^{\text {th }}$ ed. Washington, DC: CQ Press.

Gouldner, Alvin W. 1959. "Organizational Analysis." In Sociology Today, ed. Robert K. Merton, Leonard Broom, and Leonard S. Cottrell. New York: Basic Books.

Grafton, Carl. 1975. "The Creation of Federal Agencies." Administration and Society 7 (3): 328.

Hager, Mark, Joseph Galaskiewicz, Wolfgang Bielefeld, and Joel Pins. 1996. "Tales from the Grave: Organizations' Accounts of Their Own Demise." The American Behavioral Scientist 39 (8): 975-994.

Handler, Joel F. 1986. The Conditions of Discretion. New York: Russell Sage Foundation.

Hargrove, Erwin C. 1994. Prisoners of the Myth: The Leadership of the Tennessee Valley Authority. Princeton, NJ: Princeton University Press.

Henderson, Andrew D. 1999. "Firm Strategy and Age Dependence." Administrative Science Quarterly 44: 281-314.

Hood, Christopher C. 1976. The Limits of Administration. London: John Wiley \& Sons.

Kaufman, Herbert. 1971. The Limits of Organizational Change. Tuscaloosa: University of Alabama Press.

- 1976. Are Government Organizations Immortal? Washington, DC: The Brookings Institution.

. 1981. The Administrative Behavior of Federal Bureau Chiefs. Washington, DC: The Brookings Institution.

Kingdon, John W. 1984. Agendas, Alternatives and Public Policies. New York: HarperCollins.

Kleinbaum, David G, and Mitchel Klein. 2005. Survival Analysis. New York: Springer. 
Krasner, Stephen. 1984. "Approaches to the State." Comparative Politics 16 (2): 223-246.

Lewis, David E. 2002. “The Politics of Agency Termination." Journal of Politics 64 (1): 89-107.

- 2003. Presidents and the Politics of Agency Design. Stanford, CA: Stanford University Press.

- 2004 "The Adverse Consequences of the Politics of Agency Design for Presidential Management in the United States." British Journal of Political Science 34: 377-404.

Lewis, Eugene. 1980. Public Entrepreneurship. Bloomington: Indiana University Press.

Light, Paul C. 1999. A Delicate Balance. Boston: Bedford/St. Martin's.

Lorsch, Jay W, and Paul R. Lawrence, eds. 1970. Studies in Organizational Design. Homewood, IL: R.D. Irwin and the Dorsey Press.

Lowi, Theodore J. 1979. The End of Liberalism. New York: Norton.

Mashaw, Jerry L. 1983. Bureaucratic Justice: Managing Social Security Disability Claims. New Haven, CT: Yale University Press.

McCoy, Donald R. 1978. National Archives. Chapel Hill: University of North Carolina Press.

McCubbins, Matthew D., Roger Noll, and Barry Weingast. 1989. "Structure and Process, Politics and Policy." Virginia Law Review 75 (2): 431-482.

Meyer, John W, and Brian Rowan. 1977. "Institutionalizing Organizations." American Journal of Sociology 83: 340-363.

Moe, Terry M. 1989. "The Politics of Bureaucratic Structure." In Can the Government Govern? ed. John E. Chubb and Paul E. Peterson. Washington, DC: The Brookings Institution.

Parrish, Michael E. 1970. Securities Regulation and the New Deal. New Haven, CT: Yale University Press.

Perrow, Charles B. 1986. Complex Organizations: A Critical Essay. New York: Random House.

Pierson, Paul. 2000. "Increasing Returns, Path Dependence and the Study of Politics." American Political Science Review 94 (2): 251-267.

Riccucci, Norma M. 1995. Unsung Heroes. Washington, DC: Georgetown University Press.

Rose, Richard, and Philip L. Davies. 1994. Inheritance in Public Policy. New Haven, CT: Yale University Press.

Rosenbaum, Paul R. 2005. "Reasons for Effects." Chance: New Directions for Statistics and Computing 18 (1): 5-10.

Sapolsky, Harvey M. 1972. The Polaris System Development: Bureaucratic and Programmatic Success in Government. Cambridge, MA: Harvard University Press.

Seidman, Harold. 1998. Politics, Position and Power. New York: Oxford University Press.

Selznick, Philip. 1949. TVA and the Grassroots. Berkeley: University of California Press.

- 1957. Leadership in Administration. Berkeley: University of California Press.

Stinchcombe, Arthur L. 1965. "Social Structure and Organizations." In Handbook of Organizations, ed. James G. March. Chicago: Rand McNally.

Strange, Susan. 1998. "Why Do International Organizations Never Die?" In Autonomous Policymaking by International Organizations, ed. Bob Reinalda and Bert-Jan Verbeek. London: Routledge.

Suchman, Mark C. 1995. "Managing Legitimacy." Academy of Management Review 20 (3): 571-610.

Tainter, Joseph A. 1988. The Collapse of Complex Societies. Cambridge, UK: Cambridge University Press.

Van Gunsteren, Herman R. 1976. The Quest for Control. London: John Wiley. 
Whitnah, Donald R. 1983. Government Agencies. Westport, CT: Greenwood.

Wilson, James Q. 1989. Bureaucracy. New York: Basic Books.

Wolf, Patrick J. 1993. "A Case Study Survey of Bureaucratic Effectiveness in U.S. Cabinet Agencies." Journal of Public Administration Research and Theory 3 (2): 161-181.

Wood, Dan W., and Richard W. Waterman. 1994. Bureaucratic Dynamics: The Role of Bureaucracy in a Democracy. Boulder, CO: Westview Press.

\section{APPENDIX}

\section{List of Organizations in Population}

\begin{tabular}{lcc}
\hline & Creation & Termination \\
date & date \\
Organization & 1933 & Still exists \\
\hline Central Bank for Cooperatives (Cobank) & 1933 & Still exists \\
Commodity Credit Corporation & 1934 & Still exists \\
Export Import Bank & 1933 & Still exists \\
Farm Credit Administration & 1934 & Still exists \\
Federal Communications Commission & 1933 & Still exists \\
Federal Deposit Insurance Corporation & 1934 & Still exists \\
Foreign Trade Zones Board & 1935 & Still exists \\
Indian Arts and Crafts Board & 1934 & Still exists \\
National Archives Establishment (NARA) & 1934 & Still exists \\
National Historical Publications Commission & 1934 & Still exists \\
National Labor Relations Board & 1933 & Still exists \\
Procurement Division (Federal Supply Service) & 1934 & Still exists \\
Railroad Retirement Board & 1934 & Still exists \\
Securities and Exchange Commission & 1935 & Still exists \\
Social Security Administration & 1933 & Still exists \\
Tennessee Valley Authority & 1934 & 1935 \\
District of Columbia-Virginia Boundary Commission & 1933 & 1935 \\
National Recovery Administration & 1934 & 1935 \\
Office of the General Council & 1933 & 1935 \\
Petroleum Administration & 1933 & 1935 \\
Science Advisory Board & 1935 & 1936 \\
Bituminous Coal Labor Board & 1933 & 1935 \\
Federal Alcohol Control Administration & 1933 & 1936 \\
Federal Coordinator of Transportation & 1934 & 1936 \\
Second Export-Import Bank & 1934 & 1937 \\
National Steel Labor Relations Board & 1934 & 1937 \\
Textile Labor Relations Board & 1933 & 1939 \\
Central Statistical Board & 1935 & 1939 \\
National Bituminous Coal Commission & 1933 & 1938 \\
National Reemployment Service & 1935 & 1938 \\
Special Mexican Claims Commission & 1933 & 1939 \\
National Emergency Council & 1934 & 1939 \\
National Power Policy Committee & 1935 & 1938 \\
Prison Industries Reorganization Administration & 1935 & 1939 \\
Savings and Loan Division & 1934 & 1940 \\
Federal Prison Industries Incorporated & 1933 & 1940 \\
Federal Surplus Commodities/Relief Corporation & 1934 & 1941 \\
Federal Farm Mortgage Corporation & &
\end{tabular}




\begin{tabular}{lcc}
\hline Organization & $\begin{array}{c}\text { Creation } \\
\text { date }\end{array}$ & $\begin{array}{c}\text { Termination } \\
\text { date }\end{array}$ \\
\hline Civilian Conservation Corps & 1933 & 1942 \\
Electric Home and Farm Authority & 1933 & 1937 \\
Housing Division (of the PWA) & 1933 & 1937 \\
Federal Emergency Relief Administration & 1933 & 1938 \\
National (Resources) Planning Board & 1933 & 1943 \\
National Youth Administration & 1935 & 1943 \\
Public Works Administration & 1933 & 1943 \\
Works Progress Administration & 1935 & 1942 \\
Agricultural Adjustment Administration & 1933 & 1945 \\
Resettlement Administration & 1935 & 1946 \\
Division of Grazing Control & 1934 & 1946 \\
Joint Economy Board & 1933 & 1947 \\
RFC mortgage company & 1935 & 1947 \\
National Archives Council & 1934 & 1950 \\
Bureau of Entomology and Plant Quarantine & 1934 & 1953 \\
Home Owner Loan Corporation & 1933 & 1947 \\
Land Bank Commissioner & 1933 & 1953 \\
Puerto Rico Reconstruction Administration & 1935 & 1953 \\
Production Credit Corporation and Associations & 1933 & 1957 \\
Committee for Reciprocity Information & 1934 & 1963 \\
Federal Housing Administration & 1934 & 1965 \\
Federal Savings and Loan Insurance Corporation & 1934 & 1989 \\
Rural Electrification Administration & 1935 & 1994 \\
Soil Conservation Service & 1933 & 1994 \\
Immigration and Naturalization Service & 1933 & 2002 \\
& & \\
\hline
\end{tabular}

